\title{
Space use and resource selection by foraging Indiana bats at the northern edge of their distribution
}

\author{
David S. Jachowski ${ }^{1, *}$, Joshua B. Johnson ${ }^{2}$, Christopher A. Dobony ${ }^{3}$, \\ John W. Edwards ${ }^{4}$, W. Mark Ford ${ }^{5}$ \\ ${ }^{1}$ Department of Fisheries and Wildlife Conservation, 106 Cheatham Hall, Virginia Polytechnic Institute and State University, \\ Blacksburg, Virginia 24061, USA \\ ${ }^{2}$ Pennsylvania Game Commission, 2001 Elmerton Avenue, Harrisburg, Pennsylvania 17110, USA \\ ${ }^{3}$ Fort Drum Military Installation, Natural Resources Branch, 85 First Street West, IMNE-DRM-PWE, Fort Drum, \\ New York 13602, USA \\ ${ }^{4}$ Division of Forestry and Natural Resources, West Virginia University, Box 6125, Morgantown, West Virginia 26506, USA \\ ${ }^{5}$ U.S. Geological Survey, Virginia Cooperative Fish and Wildlife Research Unit, \\ Department of Fisheries and Wildlife Conservation, 106 Cheatham Hall, Virginia Polytechnic Institute and State University, \\ Blacksburg, Virginia 24061, USA
}

\begin{abstract}
Despite 4 decades of conservation concern, managing endangered Indiana bat (Myotis sodalis) populations remains a difficult wildlife resource issue facing natural resource managers in the eastern United States. After small signs of population recovery, the recent emergence of white-nose syndrome has led to concerns of local and/or regional extirpation of the species. Where Indiana bats persist, retaining high-quality foraging areas will be critical to meet physiological needs and ensure successful recruitment and overwinter survival. However, insight into foraging behavior has been lacking in the Northeast of the USA. We radio-tracked 12 Indiana bats over 2 summers at Fort Drum, New York, to evaluate factors influencing Indiana bat resource selection during night-time foraging. We found that foraging space use decreased $2 \%$ for every $100 \mathrm{~m}$ increase in distance to water and $6 \%$ for every $100 \mathrm{~m}$ away from the forest edge. This suggests high use of riparian areas in close proximity to forest and is somewhat consistent with the species' foraging ecology in the Midwest and upper South. Given the importance of providing access to high-quality foraging areas during the summer maternity season, Indiana bat conservation at the northern extent of the species' range will be linked to retention of forested habitat in close proximity to riparian zones.
\end{abstract}

KEY WORDS: Foraging $\cdot$ Home range $\cdot$ Indiana bat $\cdot$ Myotis $\cdot$ New York $\cdot$ Resource utilization function

Resale or republication not permitted without written consent of the publisher

\section{INTRODUCTION}

For over 4 decades, conservation of the federally endangered Indiana bat Myotis sodalis has been a daunting task facing natural resource managers in the eastern United States (Menzel et al. 2001, 2005). Although Indiana bats were one of the first species federally listed as endangered in 1966 under the Endangered Species Preservation Act, they still faced successive years of declines post-listing due to various factors. By the mid-2000s the species had experienced a modest growth in numbers, with much of the species' increase in numbers occurring in the Northeast. However, since the emergence of white-nose syndrome (WNS) in 2006, caused by the fungal pathogen Pseudogymnoascus destructans, over 40000 Indiana bats have died, with $95 \%$ of populations predicted to decline below extirpation thresholds in the next $50 \mathrm{yr}$ 
(Thogmartin et al. 2013). In addition to predicted ongoing disease-related declines and regional extirpation, modeled climate-change impacts predict a drastic displacement of optimal cave habitat for hibernation and summer maternity habitat from the Midwest to the central Appalachians and Northeast over the next 50 yr (Loeb \& Winters 2012), adding uncertainty to the long-term conservation of the species.

With these precipitous declines, knowledge of the roosting and foraging ecology is needed for conservation of Indiana bats (Sparks et al. 2005, Womack et al. 2013). To maximize recruitment during the maternity season and help ensure population persistence, managers need to provide quality foraging and roosting habitat (Humphrey et al. 1977). Indiana bats begin to emerge from hibernation in caves and mines in mid-April and migrate to their summer ranges (Cope \& Humphrey 1977, Kurta \& Murray 2002). At their summer ranges, female Indiana bats form day-roost maternity colonies of 20 to 100 individuals under exfoliating bark of trees or snags and in cracks or crevices (Kurta et al. 1993, Menzel et al. 2001, Kurta 2004). During the night, Indiana bats forage on insects in riparian forested areas, and in upland forested areas and other habitats to a lesser extent (Humphrey et al. 1977, LaVal et al. 1977, LaVal \& LaVal 1980, Brack 1983, Ford et al. 2005). Accordingly, in the maternity season, managers must be cognizant of both roosting and foraging habitat needs (Menzel et al. 2005). Although many aspects of Indiana day-roost ecology are understood across the bat's distribution, documentation of foraging habitat use is known from only a few radio-telemetric and acoustical studies (e.g. LaVal et al. 1977, Menzel et al. 2005, Sparks et al. 2005, Watrous et al. 2006, Womack et al. 2013).

Given their vagility, Indiana bats use much larger areas than would otherwise be expected for a similarly sized terrestrial mammal (Kelt \& Van Vuren 1999), and therefore have a greater ability to select for areas that maximize foraging efficiency. Previous studies on resource selection by Indiana bats during summer foraging periods have shown considerable foraging use plasticity contingent upon local landscape characteristics throughout the range of the species. At the western extent of their range in the central USA, where forest tracts are relatively small and fragmented, Indiana bats forage closer to forested woodlots and riparian habitats than to agricultural lands (Menzel et al. 2005, Womack et al. 2013, Kniowski 2011). Similarly, in the heavily forested landscapes of the central Appalachians, within the Allegheny Plateau of northern West Virginia, Indiana bat foraging activity was highest in mid-order forested riparian areas with moderate to full canopy cover, with very little activity elsewhere in the surrounding upland forests (Ford et al. 2005). Conversely, in the ridge and valley area of central Pennsylvania, Butchkoski \& Hassinger (2002) observed most Indiana bat foraging activity in large patches of interior, upland forests on the valley floor rather than along riparian areas or surrounding mountain side slopes and ridges. At the northern extreme of the Indiana bat distribution in the Champlain Valley of Vermont, Watrous et al. (2006) documented foraging preference for patchy land-cover types in close proximity to water and eastfacing slopes, including some use of agricultural fields. Collectively there is a fairly consistent theme of Indiana bats foraging within or near forested areas and in close association with water. However, it is clear that Indiana bats display considerable plasticity in foraging habitat use that reflects local landscape characteristics. As such, effective Indiana bat conservation in the summer maternity season probably requires region- and site-specific observations on space use and resource selection.

In this study we evaluated foraging space use and resource utilization patterns by Indiana bats at the northern edge of their range. Indiana bat populations in the Northeast of the USA are arguably the most imperiled, by virtue of being exposed to WNS for the longest period, both in terms of time since advent of the disease and annual duration (longer) of hibernation (Ford et al. 2011). To better inform managers in this region about Indiana bat habitat requirements during the maternity season and to provide insight for post-WNS habitat conservation and management, we evaluated multiple competing hypotheses of habitat-based factors that could influence Indiana bat foraging space use and resource selection patterns.

\section{MATERIALS AND METHODS}

\section{Study area}

We conducted our study within and adjacent to Fort Drum, a >43 000 ha US Army installation in Jefferson and Lewis counties, New York, USA. Located in the northwestern portion of the state, Fort Drum lies at the intersection of 3 eco-regions: the Tug Hill Plateau, the St. Lawrence/Great Lakes Lowlands, and the foothills of the Adirondack Mountains. Limestone 'karst' formations in the Niagara Escarpment are situated 10 to $15 \mathrm{~km}$ west of Fort Drum and contain caves where bats hibernate. Topography is rolling with some incised water-courses along the 
Black and Indian river drainages. Elevations range from 125 to $278 \mathrm{~m}$. Approximately $70 \%$ of Fort Drum is forested. Mature forests are northern hardwood associations of sugar maple Acer saccharum, American beech Fagus grandifolia, white ash Fraxinus americana, and American elm Ulmus americana mixed with a conifer component of white pine Pinus strobus and eastern hemlock Tsuga canadensis. In addition to developed areas within the installation's 4500 ha cantonment area and airfield, open habitats maintained for training such as drop-zones, firing ranges, maneuver areas, and forest regeneration areas occur throughout. Small lakes, beaver (Castor canadensis) ponds, and open wet meadows cover approximately $20 \%$ of the landscape. Lands adjacent to Fort Drum include similar elevations and forest associations; however, forested areas are highly fragmented and interspersed with agricultural row crops, pastureland, and areas of urban sprawl development.

\section{Capture and handling}

We captured Myotis sodalis in 2008 and 2009 by setting up 6, 9, and $12 \mathrm{~m}$ wide double-stacked mesh (38 mm) mist nets (Avinet, Dryden, NY) opportunistically over dirt roads and trails, with some in the interior forest, along edges, and occasionally over water. Mist nets were open for $\geq 4 \mathrm{~h}$ following sunset. Upon capturing a bat, we determined species, sex, age, weight, forearm length, and reproductive condition (Menzel et al. 2002). We used Skin Bond $®$ (Smith and Nephew, Largo, FL) surgical cement to affix a $0.35 \mathrm{~g}$ radio transmitter (Blackburn Transmitters, Nacogdoches, TX) between the scapulae of each captured Indiana bat. Bat capture and handling protocols were approved by the Animal Care and Use Committee of West Virginia University (Protocol No. 08-0504) and followed the guidelines of the American Society of Mammalogists (Sikes et al. 2011). The average weight of captured bats was $7.44 \mathrm{~g}(\mathrm{n}=15, \mathrm{SE}=0.20$, range $=6.5-8.9 \mathrm{~g}$ ), and the average radio-transmitter to body mass ratio was $4.76 \%$ ( $\mathrm{SE}=0.12$, range $=$ $3.93-5.38 \%$ ), below the $5 \%$ threshold recommended for minimizing the effects of transmitters on bat movement (Aldridge \& Brigham 1988).

\section{Monitoring}

To monitor movement of radio-marked Indiana bats, we established a network of radio-telemetry stations, both within and outside of Fort Drum Mili- tary Installation. We commenced radio-telemetry after bats emerged from their roost trees at dusk. Given the ability of Indiana bats to move relatively long distances in 5 min periods, we assumed sufficient spatial independence between locations for subsequent space use and resource selection by attempting to locate bats at 5 min intervals (Womack et al. 2013). We attempted to triangulate the location of individual radio-tagged bats by having 2 or 3 observers simultaneously use radio receivers and 3-element Yagi antennae to obtain directional azimuths (White \& Garrott 1990). We ceased obtaining azimuths when steady transmitter signals were received, indicating the bat was night-roosting. We estimated point locations where bats were flying by entering radiotelemetry station locations and directional azimuth data into LOCATE 3 (Nams 2006).

\section{Foraging space use}

We represented foraging space use by creating a utilization distribution (UD) for each bat for which $\geq 29$ nighttime locations were collected. UDs create a 3-dimensional grid based on animal relocations that estimate the probability of use by a bat throughout its home range (Kernohan et al. 2001). We calculated a UD for each bat using the kde package in the program R, Version 2.10.0 (R Core Team 2010), using the plug-in method for bandwidth selection (Gitzen et al. 2006). We then trimmed each UD by its $95 \%$ volume contour using Hawthtools extension in ArcGIS, and the resulting perimeter representing the bat's $95 \%$ fixed kernel home range.

\section{Resource selection analyses}

We developed 14 a priori hypotheses of factors influencing resource utilization based on a literature review of important habitat features in past Indiana bat resource selection studies throughout their range (Table 1). We categorized habitat into upland mixed forest, forested wetland, shrub wetland, agricultural/ field habitats, or developed, based on Northeast Terrestrial Habitat Classification System land-cover maps (Wildlife Management Institute 2012). Dummy variable coding for categorical variables required that 1 category be removed prior to model fitting. Because the upland mixed forest category was the dominant land-cover category, we removed it to serve as a reference category. We also developed 6 continuous variables for use in our resource selection 
Table 1. Foraging resource use models developed from a literature review, based on factors we hypothesized to influence Indiana bat (Myotis sodalis) foraging resource use near Fort Drum, New York, 2008 to 2009

\begin{tabular}{|c|c|c|c|}
\hline Model no. & Hypothesis & Model & References \\
\hline 1 & Use decreases as distance from water increases & DisW & $\begin{array}{l}\text { Menzel et al. (2005), } \\
\text { Watrous et al. (2006) }\end{array}$ \\
\hline 2 & Use decreases as distance from forest edge increases & DisF & $\begin{array}{l}\text { Brack (1983), Menzel } \\
\text { et al. (2001) }\end{array}$ \\
\hline 3 & $\begin{array}{l}\text { Use decreases as proximity to disturbed/developed } \\
\text { areas decreases }\end{array}$ & DisD & $\begin{array}{l}\text { Sparks et al. (2005), } \\
\text { Menzel et al. (2005) }\end{array}$ \\
\hline 4 & Use decreases on steep slopes and high elevation & SLP - ELEV & Watrous et al. (2006) \\
\hline 5 & Use decreases on north-facing slopes & ASP & Watrous et al. (2006) \\
\hline 6 & $\begin{array}{l}\text { Use increases in upland forest as well as forested } \\
\text { wetland; decreases in shrub wetland, agricultural, } \\
\text { and developed areas }\end{array}$ & LAND & $\begin{array}{l}\text { Bowles (1981), Menzel } \\
\text { et al. (2005), Womack } \\
\text { et al. (2013) }\end{array}$ \\
\hline 7 & $\begin{array}{l}\text { Use increases in upland and wetland forest, } \\
\text { particularly in areas near forest edges }\end{array}$ & LAND - DisF & Menzel et al. (2001) \\
\hline 8 & $\begin{array}{l}\text { Use increases in upland and wetland forest along } \\
\text { south-facing slopes }\end{array}$ & LAND + ASP & \\
\hline 9 & $\begin{array}{l}\text { Use increases in upland and wetland forest, } \\
\text { particularly in areas near water }\end{array}$ & LAND - DisW & $\begin{array}{l}\text { Bowles (1981), Womack } \\
\text { et al. (2013) }\end{array}$ \\
\hline 10 & $\begin{array}{l}\text { Use increases in flat, upland, and wetland forest, } \\
\text { and decreases at high elevation }\end{array}$ & LAND - SLP - ELEV & Watrous et al. (2006) \\
\hline 11 & $\begin{array}{l}\text { Use increases in upland and wetland forest that } \\
\text { is in close proximity to water and further away } \\
\text { from development }\end{array}$ & LAND + DisD - DisW & \\
\hline 12 & $\begin{array}{l}\text { Use increases in upland and wetland forest that } \\
\text { is in close proximity to forest edge and open water }\end{array}$ & $\mathrm{SLP}+\mathrm{ASP}-\mathrm{DisF}-\mathrm{DisW}$ & \\
\hline 13 & $\begin{array}{l}\text { Use increases in upland and wetland forest that } \\
\text { is in close proximity to forest edge, open water, } \\
\text { flat slopes, and away from development }\end{array}$ & DisD - DisF - DisW - SLP & \\
\hline 14 & Global & $\begin{array}{l}\text { LAND - DisF - DisW + } \\
\text { DisD + ASP - SLP - ELEV }\end{array}$ & \\
\hline
\end{tabular}

models (Table 1). Indiana bats have been found to select for foraging areas near forest edge (Brack 1983, Menzel et al. 2001); therefore, we used the Euclidean distance function in ArcGIS 9.3 (ESRI, Redlands, CA) to include a metric for distance to forest edge (DisF; a generalized category for all 3 types of forest listed above). Multiple studies have found that Indiana bats prefer to forage near water (Kurta \& Whitaker 1998, Menzel et al. 2005, Watrous et al. 2006). Thus, we included a positive effect of being near open water (i.e. lakes and ponds) or streams (DisW). Also, Indiana bats preferentially forage in wooded areas rather than developed areas at a ruralurban interface in Indiana (Sparks et al. 2005, Menzel et al. 2005). Therefore, we developed distance metrics representing the likely avoidance of developed areas (DisD) (Sparks et al. 2005).

We included measures of both aspect and slope, which have been found to be important factors in Indiana bat space use, particularly in the north and in the Appalachians (Watrous et al. 2006). We obtained slope and aspect measures by downloading US Geological Survey digital elevation models for the study area from the New York State GIS Clearinghouse (www.gis.ny.gov, accessed June 2013). We first hypothesized that Indiana bats would preferentially forage in areas of less topographic complexity (Watrous et al. 2006). Where pronounced relief and topographic complexity existed, we predicted that bats would preferentially forage on or near southfacing slopes due to warmer temperatures. Because aspect is based on circular degrees, we transformed angular data to radians and centered our metric on the south aspect using $\cos ($ aspect $)+1$ which yielded values that ranged from 0 (at $180^{\circ}$, or S) to 2 (at 0 and $360^{\circ}$, or N). We also hypothesized that space use would decrease with increasing upland elevation (Watrous et al. 2006). Once each of these habitat attributes was spatially defined across our study area, we used ArcGIS to intersect UD grid node points with habitat covariates to extract point-specific covariate values. 


\section{Model fitting and selection}

We developed a resource utilization function (RUF) to examine the relationship between space use and resource attributes for each of our 12 individual bats. Through the RUF calculation we used the height ( $z$-value) of the UD at each grid point as the response variable in a multiple regression analysis that included combinations of predictor variables that represent the hypotheses outlined above (Marzluff et al. 2004). Prior to analysis, we clipped each bat UD by its $99 \%$ volume contour and re-standardized the values of each bat UD into 100 UD percentiles, so that the probability of use was on a scale of 0 to 100 , with 100 representing the highest probability of use (Jachowski et al. 2013, Montgomery et al. 2013). We evaluated support for our models (Table 1) using Akaike's Information Criteria corrected for small sample size $\left(\mathrm{AIC}_{\mathrm{c}}\right)$ (Burnham \& Anderson 2002) in the program R (Version 2.10.0). We were unable to evaluate all models for 2 of the bats we tracked. We excluded the categorical variable of shrub wetland for 2 bats because their UDs did not overlap those 2 habitat types. Following model fitting, we identified the top-ranked model as the model(s) assigned $>90 \%$ of the $\mathrm{AIC}_{\mathrm{c}}$ model weights $\left(w_{i}\right)$ (Burnham \& Anderson 2002). If there was model uncertainty, we used model averaging to create a single most supported model for each bat based on Akaike weights (Burnham \& Anderson 2002). To create a population-level model, we averaged the most-supported models across all individuals (Marzluff et al. 2004, Jachowski et al. 2011), and then projected predicted foraging use across the larger Fort Drum landscape.

\section{Model validation}

We evaluated the predictive ability of our foraging RUF for Fort Drum using 2 approaches. We first used a $k$-fold cross-validation approach (Boyce et al. 2002), where we randomly selected $20 \%$ of UD cells (the testing set) from the UD of an individual bat and recalculated the RUF using the remaining data (the training set). We then iteratively repeated this procedure 5 times to produce 5 sets each of training and testing data for each bat. We then used the estimated coefficients from the training data to predict RUF values for the withheld testing $(20 \%)$ data set. We classified RUF scores into 20 equal-interval categories or bins based on distribution of values in each sampling subset and examined the correlation between training and testing data using a Spearman-rank correlation (Jachowski et al. 2011). We expected a model with good predictive ability to have a high, positive cross-validated Spearman-rank correlation value $\left(\mathrm{r}_{\mathrm{s}}\right)$.

\section{RESULTS}

In 2008, we conducted surveys for the bats between 12 May and 16 September, mist netting for 28 nights at 23 locations. In 2009, we conducted surveys between 11 May and 22 September, mist netting for 59 nights at 24 locations. We captured 11 Indiana bats in 2008 and 4 Indiana bats in 2009 . We attached radiotransmitters to the 15 Indiana bats captured over the 2 field seasons. On average, we were able to radiotrack each Indiana bat for 6.83 nights $(\mathrm{SE}=0.85$, range $=3-15$ ), gaining 70.75 radio-fix locations per bat $(\mathrm{SE}=13.82$, range $=14-200)($ Table 2$)$. Overall, we col-

Table 2. Survey details and home range metrics for the 12 Indiana bats Myotis sodalis monitored near Fort Drum, New York, 2008 to 2009. Some roosts were identified on nights when foraging was not tracked for an individual bat. A: adult; J: juvenile; M: male; F: female

\begin{tabular}{|c|c|c|c|c|c|c|c|c|}
\hline Bat ID & Age & Sex & Year & Month & $\begin{array}{l}\text { No. of nights } \\
\text { tracked }\end{array}$ & $\begin{array}{l}\text { No. of } \\
\text { locations }\end{array}$ & $\begin{array}{l}\text { No. of } \\
\text { roosts }\end{array}$ & $\begin{array}{c}95 \% \text { fixed kernel } \\
\text { home range size (ha) }\end{array}$ \\
\hline 1 & A & M & 2008 & May & 4 & 29 & 5 & 18.94 \\
\hline 2 & A & $\mathrm{F}$ & 2008 & May & 5 & 33 & 8 & 95.25 \\
\hline 3 & A & $\mathrm{F}$ & 2008 & Jul & 6 & 47 & 4 & 318.02 \\
\hline 4 & A & $\mathrm{F}$ & 2008 & Jul & 5 & 33 & 5 & 75.46 \\
\hline 5 & $\mathrm{~J}$ & M & 2008 & Aug & 8 & 84 & 3 & 282.98 \\
\hline 6 & $\mathrm{~J}$ & $\mathrm{~F}$ & 2008 & Sep & 9 & 52 & 9 & 111.89 \\
\hline 7 & A & $\mathrm{F}$ & 2009 & Jul & 7 & 76 & 7 & 150.37 \\
\hline 8 & A & $\mathrm{F}$ & 2009 & Jun & 6 & 91 & 3 & 43.56 \\
\hline 9 & A & $\mathrm{F}$ & 2009 & Jul & 7 & 134 & 4 & 243.6 \\
\hline 10 & $\mathrm{~J}$ & M & 2009 & Aug & 15 & 200 & 8 & 64.54 \\
\hline 11 & A & M & 2008 & Sep & 7 & 40 & 8 & 38.32 \\
\hline 12 & $\mathrm{~J}$ & $\mathrm{~F}$ & 2008 & Aug & 3 & 30 & 1 & 122.67 \\
\hline
\end{tabular}


Table 3. Number of times each model of Indiana bat (Myotis sodalis) resource utilization function received the most support for explaining resource selection of an individual Indiana bat $(n=12)$ near Fort Drum, New York, 2008 to 2009. na: not applicable

\begin{tabular}{|c|c|c|c|c|}
\hline \multirow[t]{2}{*}{ Model } & \multicolumn{2}{|c|}{${ }_{-}$Females } & \multicolumn{2}{|c|}{ Males } \\
\hline & No. times & Avg. Akaike weight & No. times & Avg. Akaike weight \\
\hline (9) LAND - DisW & 1 & 1.00 & 0 & na \\
\hline (10) LAND - SLP - ELEV & 0 & na & 1 & 1.00 \\
\hline (11) LAND + DisD - DisW & 4 & 0.98 & 1 & 1.00 \\
\hline (13) DisD - DisF - DisW - SLP & 2 & 1.00 & 0 & na \\
\hline (14) LAND - DisF - DisW + DisD + ASP - SLP - ELEV & 1 & 1.00 & 2 & 1.00 \\
\hline
\end{tabular}

lected $\geq 29$ locations (our minimum sample size required for UD calculation) during a survey season for 12 ( 2 adult males, 2 juvenile males, 6 adult females, 2 juvenile females) of the 15 Indiana bats.

\section{Space use}

The mean $95 \%$ fixed kernel home range size for the 12 bats was 130.47 ha $(\mathrm{SE}=28.75$, range $=18.94-$ 318.02) (Table 2). Unfortunately, small sample sizes limited our ability to test for an effect of bat sex or age class on home range size.

\section{Resource selection}

We observed a low amount of model uncertainty but a relatively high amount of variation in resource utilization by individual Indiana bats (Table 3). Although small sample sizes prohibited us from mak-

Table 4. Mean cross-validated $(\mathrm{n}=5$ ) Spearman-rank correlations $\left(\mathrm{r}_{\mathrm{s}}\right)$ between resource utilization function bin ranks for testing the population-level model on individual Indiana bats Myotis sodalis near Fort Drum, New York, 2008 to 2009. $\mathrm{r}_{\mathrm{s}}$ values close to 1 indicate strong support for predictive ability of our global, population-level model

\begin{tabular}{|lccc|}
\hline Bat ID & $\mathrm{r}_{\mathrm{s}}$ & $\mathrm{SE}$ & $\mathrm{p}$ \\
\hline 1 & 0.9889 & 0.0043 & $<0.0001$ \\
2 & 0.9345 & 0.0382 & $<0.0001$ \\
3 & 0.9765 & 0.0054 & $<0.0001$ \\
4 & 0.9912 & 0.0027 & $<0.0001$ \\
5 & 0.9901 & 0.0020 & $<0.0001$ \\
6 & 0.9995 & 0.0010 & $<0.0001$ \\
7 & 0.9965 & 0.0016 & $<0.0001$ \\
8 & 0.9843 & 0.0013 & $<0.0001$ \\
9 & 0.9899 & 0.0013 & $<0.0001$ \\
10 & 0.9893 & 0.0018 & $<0.0001$ \\
11 & 0.9971 & 0.0010 & $<0.0001$ \\
12 & 0.9899 & 0.0053 & $<0.0001$ \\
\hline
\end{tabular}

ing sex-specific generalizations, across both sexes we found some support for the inclusion of each of our predictive covariates in our most supported models: land cover, slope, aspect, elevation and distance to water, forest, and development. Therefore, our population-level model contained all predicted covariates (i.e. the global model). We found further evidence of support for the global model through $k$-fold cross validation of our averaged, population-level model, where the mean cross-validated Spearmanrank correlation values $\left(r_{s}\right)$ were $\geq 0.9345(p<0.0001)$ (Table 4).

The interspersion of forested habitat and open water was correlated with patterns in Indiana bat resource selection. In comparison to the upland mixed forest land-cover type that dominated our study area on and surrounding Fort Drum, Indiana bat probability of use during foraging bouts was consistently lower in agricultural habitats and shrub wetland habitats (Table 5). We found that most bats

Table 5. Averaged, population-level resource use coefficients (with associated variance) for Indiana bats Myotis sodalis $(\mathrm{n}=12)$ near Fort Drum, New York, 2008 to 2009. When a covariate was included in the top-ranked model for an individual Indiana bat, we tallied the direction ( $\beta$ value + or -$)$ for individual bats of use in relation to resource coefficient

\begin{tabular}{|lrrr|}
\hline Habitat covariate & $\beta$ (SE) & + & - \\
\hline Intercept $^{\text {Developed }}{ }^{\mathrm{a}}$ & $11.0687(60.38)$ & 9 & 3 \\
Agriculture $^{\mathrm{a}}$ & $-3.7634(7.89)$ & 3 & 7 \\
Forested wetland $^{\mathrm{a}}$ & $-9.0769(8.58)$ & 1 & 9 \\
Shrub wetland $^{\mathrm{a}}$ & $1.6911(6.84)$ & 5 & 4 \\
Distance to forest edge $_{\text {Distance to water }}$ & $-14.4558(8.82)$ & 2 & 7 \\
Distance to development & $-0.0579(0.14)$ & 2 & 3 \\
Aspect & $-0.0184(0.03)$ & 3 & 8 \\
Slope & $0.0400(0.05)$ & 8 & 2 \\
Elevation & $0.7587(0.94)$ & 2 & 1 \\
aDummy variable coded as 1 if within habitat type; mixed \\
forest was the reference category \\
\hline
\end{tabular}


were less likely to forage in developed areas and that predicted foraging use increased as distance from development increased (Table 5). Use of forested wetlands varied among bats, and coefficient standard errors overlapped zero, suggesting that use of these habitat types could be equivalent with upland mixed forest (Table 5). Predicted foraging space use decreased $6 \%$ and $2 \%$ for every $100 \mathrm{~m}$ away from forest edge and open water sources respectively. Although standard errors of these 2 population-level parameter coefficients overlapped zero, 8 of the 11 bats showed a negative association with increased distance from open water, suggesting higher use of areas near water (Table 5).

For the 6 bats that retained topographic features in their top predictive model, we observed a high amount of variation in the effect of percent slope, aspect, and elevation among individual bats. Standard errors for population-level coefficients overlapped 0 for each topographic feature, and positive or negative effect on resource use varied considerably among individual bats, preventing us from making any population-level generalizations (Table 5). Further, bats remained in the southern portion of the study area and exhibited limited variability in elevation compared to the higher northern section of the installation, limiting our ability to effectively evaluate the role of elevation in resource utilization.

\section{DISCUSSION}

Given the high vagility of the species, the similarity of Indiana bat home range size estimates among previous studies throughout its distribution suggests that the species can adjust space use within their home ranges to meet energetic requirements rather than expand their home ranges in relation to site-specific attributes. Although differences in methodology exist among studies, our home range estimates are fairly congruent with those of others (Rommé et al. 2002, Menzel et al. 2005, Sparks et al. 2005, Watrous et al. 2006). Therefore, it is likely that a maximum home range size threshold exists to fulfill their physiological and behavioral requirements (McNab 1963) and that resource selection likely occurs at fine spatial scales within home ranges.

Within Indiana bat home ranges, foraging space use likely varies based on site-specific patterns in the availability and arrangement of forested and nonforested habitats. In the heavily agricultural settings of the Midwest, Indiana bats have been shown to prefer foraging in closed canopy forests versus open agricultural (Womack et al. 2013) or developed areas with a significant residual forested component (Sparks et al. 2005). By contrast, in the Northeast, where forests dominate the landscape, Watrous et al. (2006) observed that Indiana bats forage more in open or patchy habitats, even selecting agricultural fields in some instances. In our study area, we found evidence for avoidance of open shrub wetlands, agricultural habitats, and disturbed areas, but found a positive association of use with proximity to forest edge. Collectively, this suggests that forested habitats and edges of forest habitat are important foraging areas for Indiana bats in the northern portion of their range. One caveat to this observation is that, given the need for bats to access roost trees during the day (and even during periods of the night), our attempt to monitor 'foraging' movements could have been biased due to including movement to and from roost trees that were located primarily in forest stands composed of select deciduous tree species, such as sugar maple and American elm (C. Dobony unpubl. data). This suggests the need for subsequent analyses to evaluate the potential effect of the proximity of daytime roost locations on foraging space use, particularly if forest stands with suitable roost conditions in terms of intra-stand composition and decadent condition/structure are limited in their distribution at Fort Drum. Otherwise the availability of high-quality foraging habitat for Indiana bats may, potentially be overestimated.

Nonetheless, use of forested environments that are in close proximity to water as foraging areas is highly congruent with previous observations that Indiana bats in the northern portion of their range forage for insects associated with aquatic environments (Humphrey et al. 1977, Kurta \& Whitaker 1998, Watrous et al. 2006). Indiana bats and other Myotine species have relatively low wing loading; this enables a greater ability to maneuver and forage in such areas of structural complexity (Norberg \& Rayner 1987, Kalcounis \& Brigham 1995). Within these structurally complex foraging environments along riparian zones, our failure to differentiate use among forest types suggests that Indiana bats were selecting forested habitats near water based more on structure and canopy cover, as opposed to forest type or tree species composition. Therefore, we suggest that managers focus on ensuring the availability of forested habitats of high structural complexity near open water sources.

The impact of land development can negatively affect Indiana bats by removing roost trees (Menzel et al. 2001), but our findings suggest that it is unlikely 
that land development alone will deter Indiana bat foraging, provided forest and edge habitats near open water remain available. Our mixed support for development having a negative effect on Indiana bat foraging behavior is supported by previous studies from highly developed landscapes in the Midwest, where Indiana bats tolerate and forage over nearby agricultural fields (Menzel et al. 2005, Womack et al. 2013) and even airport runways (Sparks et al. 2005). Therefore, minimization and mitigation of human disturbances (particularly near riparian and forest habitats) seems prudent, but small amounts of human disturbance are unlikely to negatively impact Indiana bat foraging activity.

\section{Management implications}

Clearly, in comparison to WNS, roosting and foraging habitat may not be as strong a limiting factor impacting Indiana bats at present. However, persistence and recovery of remnant populations will rely on awareness of local or regional requirements of Indiana bats. Whereas considerable focus is placed on the identification and retention of suitable roost trees for Indiana bats, because the availability of high-quality foraging areas is critical to meeting the physiological needs of individual bats and ensuring recruitment and overwinter survival, foraging areas should also be an important conservation concern during the summer maternity season (Menzel et al. 2005, Womack et al. 2013). Accordingly, retention of a forest and water association should be a primary concern in the northern portion of the range. Where wetland and/or water associations change through succession or altered hydrology and only upland forests are retained, Indiana bat foraging use may decline or cease altogether. Future attempts to better elucidate conservation strategies for Indiana bats should account for year-round bat resource requirements, including overwinter hibernacula, spring and fall movement corridors, summer roost trees, and high-quality foraging habitat conditions during the summer maternity season.

Acknowledgements. We thank K. Cunningham for assistance in fieldwork and study design. We thank L. Coleman and E. Britzke for helpful comments on analyzing the data and improving the manuscript. This work was funded by financial and in-kind contributions of the Department of the Army, Fort Drum, the U.S. Army Engineer and Research Development Center, and the U.S. Forest Service, Northern Research Station. The use of any trade, product, or firm name does not imply endorsement by the US government.

\section{LITERATURE CITED}

Aldridge HD, Brigham RM (1988) Load carrying and maneuverability in an insectivorous bat: a test of the $5 \%$ 'rule' of radio-telemetry. J Mammal 69:379-382

Bowles JB (1981) Summer status of the Indiana bat in Iowa. Bat Res News 22:34

Boyce MS, Vernier PR, Nielsen SE, Schmiegelow FK (2002) Evaluating resource selection functions. Ecol Modell 157: 281-300

Brack VW (1983) The nonhibernating ecology of bats in Indiana with emphasis on the endangered Indiana bat, Myotis sodalis. PhD dissertation, Purdue University, West LaFayette, IN

Burnham KP, Anderson DR (2002) Model selection and inference: a practical information theoretic approach, 2nd edn. Springer-Verlag, New York, NY

Butchkoski CM, Hassinger JD (2002) Ecology of a maternity colony roosting in a building. In: Kurta A, Kennedy J (eds) The Indiana bat: biology and management of an endangered species. Bat Conservation International, Austin, TX, p 130-142

$>$ Cope JB, Humphrey SR (1977) Spring and autumn swarming behavior in the Indiana bat, Myotis sodalis. J Mammal 58:93-95

Ford WM, Menzel MA, Rodrigue JL, Menzel JM, Johnson JB (2005) Relating bat species presence to simple habitat measures in a central Appalachian forest. Biol Conserv 126:528-539

Ford WM, Britzke ER, Dobony CA, Rodrigue JL, Johnson JB (2011) Patterns of acoustical activity of bats prior to and following white-nose syndrome occurrence. J Fish Wild Manage 2:125-134

Gitzen RA, Millspaugh JJ, Kernohan BJ (2006) Bandwidth selection for fixed-kernel analysis of animal utilization distributions. J Wildl Manage 70:1334-1344

Humphrey SR, Richter AR, Cope JB (1977) Summer habitat and ecology of the endangered Indiana bat, Myotis sodalis. J Mammal 58:334-346

Jachowski DS, Millspaugh JJ, Biggins DE, Livieri TM, Matchett MR, Rittenhouse CD (2011) Resource selection by black-footed ferrets in South Dakota and Montana. Nat Areas J 31:218-225

Jachowski DS, Montgomery RA, Millspaugh JJ, Slotow R (2013) Unravelling complex associations between physiological state and movement of African elephants. Funct Ecol 27:1166-1175

> Kalcounis MC, Brigham RM (1995) Intraspecific variation in wing loading affects habitat use by little brown bats (Myotis lucifugus). Can J Zool 73:89-95

Kelt DA, Van Vuren D (1999) Energetic constraints and the relationship between body size and home range area in mammals. Ecology 80:337-340

Kernohan BJ, Gitzen RA, Millspaugh JJ (2001) Analysis of animal space use and movements. In: Millspaugh JJ, Marzluff JM (eds) Radio tracking and animal populations. Academic Press, San Diego, CA, p 125-166

Kniowski AB (2011) Summer ecology of the Indiana bat (Myotis sodalis) in an agricultural landscape. MS thesis, Ohio State University, Columbus, $\mathrm{OH}$

Kurta A (2004) Roosting ecology and behavior of Indiana bats (Myotis sodalis) in summer. In: Vories KC, Harrington A (eds) Proceedings of the Indiana bat and coal mining: a technical interactive forum. US Department of the Interior forum, Office of Surface Mining, Alton, IL, p 29-38 
Kurta A, Murray SW (2002) Philopatry and migration of banded Indiana bats (Myotis sodalis) and effects of radio transmitters. J Mammal 83:585-589

Kurta A, Whitaker JO (1998) Diet of the endangered Indiana bat (Myotis sodalis) on the northern edge of its range. Am Midl Nat 140:280-286

Kurta A, King D, Teramino JA, Stribley JM, Williams KJ (1993) Summer roosts of the endangered Indian bat (Myotis sodalis) on the northern edge of its ranges. Am Midl Nat 129:132-138

LaVal RK, LaVal ML (1980) Ecological studies and management of Missouri bats, with emphasis on cave-dwelling species. Missouri Department of Conservation, Jefferson City, MO

LaVal RK, Clawson RL, LaVal ML, Caire W (1977) Foraging behavior and nocturnal activity patterns of Missouri bats, with emphasis on the endangered species Myotis grisescens and Myotis sodalis. J Mammal 58:592-599

Loeb SC, Winters EA (2012) Indiana bat summer maternity distribution: effects of current and future climates. Ecol Evol 3:103-114

Marzluff JM, Millspaugh JJ, Hurvitz P, Handcock MS (2004) Relating resources to a probabilistic measure of space use: forest fragments and Steller's jays. Ecology 85: 1411-1427

McNab BK (1963) Bioenergetics and the determination of home range size. Am Nat 97:133-140

Menzel MA, Menzel JM, Carter TC, Ford WM, Edwards JW (2001) Review of the forest habitat relationships of the Indiana bat (Myotis sodalis). General Tech Rep NE-284, US Department of Agriculture, Northeastern Research Station, Newtown Square, PA

Menzel MA, Menzel JM, Castleberry SB, Ozier J, Ford WM, Edwards JW (2002) Illustrated key to skins and skulls of bats in the southeastern and mid-Atlantic States. Research Note NE-376, US Department of Agriculture, Northeastern Research Station, Newtown Square, PA

Menzel JM, Ford WM, Menzel MA, Carter TC, Gardner JE, Garner JD, Hofmann JE (2005) Summer habitat use and home-range analysis of the endangered Indiana bat. J Wildl Manage 69:430-436

Editorial responsibility: Paul Racey,

Helston, UK
Montgomery RA, Roloff GJ, Millspaugh JJ (2013) Variation in elk response to roads by season, sex and road type. J Wildl Manage 77:313-325

Nams VO (2006) Locate III user's guide. Pacer Computer Software, Tatamagouche

Norberg UM, Rayner JM (1987) Ecological morphology and flight in bats (Mammalia; Chiroptera): wing adaptations, flight performance, foraging strategy and echolocation. Philos Trans R Soc Lond B 316:335-427

R Core Team (2010) R: a language and environment for statistical computing. $\mathrm{R}$ Foundation for Statistical Computing, Vienna. www.r-project.org (accessed 1 Jun 2013)

Rommé RC, Henry AB, King RA, Glueck T, Tyrell K (2002) Home range near hibernacula in spring and autumn. In: Kurta A, Kennedy J (eds) The Indiana bat: biology and management of an endangered species. Bat Conservation International, Austin, TX, p 153-158

Sikes RS, Gannon WL and the Animal Care and Use Committee of the American Society of Mammalogists (2011) Guidelines of the American Society of Mammalogists for the use of wild mammals in research. J Mammal 92: 235-253

Sparks DW, Ritzi CM, Duchamp JE, Whitaker JO (2005) Foraging habitat of the Indiana bat (Myotis sodalis) at an urban-rural interface. J Mammal 86:713-718

> Thogmartin WE, Sanders-Reed CA, Szymanski JA, McKann PC and others (2013) White-nose syndrome is likely to extirpate the endangered Indian bat over large parts of its range. Biol Conserv 160:162-172

Watrous KS, Donovan TM, Mickey RM, Darling SR, Hicks AC, Von Oettingen SL (2006) Predicting minimum habitat characteristics for the Indiana bat in the Champlain Valley. J Wildl Manage 70:1228-1237

Wildlife Management Institute (2012) Northeast terrestrial habitat classification system. http://rcngrants.org/content/ creation-regional-habitat-cover-maps-application-northeast-terrestrial-habitat (accessed 1 Nov 2013)

Womack KM, Amelon SK, Thompson FR (2013) Resource selection by Indiana bats during the maternity season. J Wildl Manage 77:707-715

Submitted: December 16, 2013; Accepted: February 25, 2014 Proofs received from author(s): May 12, 2014 